\title{
Synthesis of a Spore-specific Surface Antigen During Sporulation of Saccharomyces cerevisiae
}

\author{
By IAN W. DAWES, ${ }^{*}$, STUART DONALDSON, ${ }^{1}$ RUTH EDWARDS ${ }^{1}$ \\ AND JOAN DAWES ${ }^{2}$ \\ ${ }^{1}$ Department of Microbiology, University of Edinburgh, Edinburgh, EH9 3JG, U.K. \\ ${ }^{2}$ Medical Research Council Immunoassay Team, Edinburgh EHI 3QW, U.K.
}

(Received 11 August 1982; revised 15 October 1982)

\begin{abstract}
Antisera raised against purified yeast ascospores caused agglutination of both ascospores and vegetative cells. A spore-specific activity was obtained by absorbing out anti-vegetative activity with vegetative cells. The anti-vegetative cell activity was directed against mannan, and was probably due to exposure of some spore coat mannan at the spore surface since concanavalin $\mathrm{A}$ and lentil lectin also caused agglutination of ascospores. The spore-specific activity was probably determined by a protein or proteins, since extraction of spores with a mixture of sodium dodecyl sulphate and dithiothreitol markedly affected their agglutination by the sporespecific serum.

The spore-specific antigen was synthesized in a soluble form during sporulation several hours before the appearance of the spore surface and the pool of soluble antigen declined as the spore was assembled. Synthesis of the soluble antigen was inhibited by adding cycloheximide at all times up to its first appearance in the sporulating cell.
\end{abstract}

\section{INTRODUCTION}

Yeast sporulation is an example of a cellular differentiation process in an organism that is amenable to detailed biochemical and genetic analysis. From genetic studies of asporogenous mutants, it has been estimated that about 50 genes are essential to the process, but not to vegetative growth (Esposito et al., 1972), and many other genes that are involved in other phases of the yeast life cycle also play a part (Esposito \& Klapholz, 1981). To date, however, only a few biochemical events that are unique to meiosis and spore formation have been analysed in detail.

An event that appears to be unique to sporulation is the synthesis of a spore surface antigen detected by Snider \& Miller (1966), who showed that spore coats were serologically distinct from asci and vegetative cell surfaces. Antisera raised against purified spores caused agglutination of spores, but not of vegetative cells or asci. The nature of this spore surface antigen was not studied, although it is clear from electron microscopy that the outer surface of the ascospore coat is a densely staining layer that has no counterpart in the vegetative cell wall. Electrophoretic studies of spore mobility and electron microscopy of spores treated with proteinases or $8 \mathrm{M}$-urea have indicated that this outer layer is composed at least in part of protein (Briley et al., 1970). In this paper, the spore surface antigen has been characterized in further detail, and the mechanism and timing of its synthesis investigated.

\section{METHODS}

Organism. Saccharomyces cerevisiae strain $60 \times 61\left(\frac{M A T a}{M A T \alpha} \frac{H O}{H O} \frac{H M L \alpha}{H M L a} \frac{H M R a}{H M R a} \frac{\text { ade2-40 }}{\text { ade2-119 }} \frac{\text { his4-239 }}{\text { his4-166 }} \frac{\text { ARG4 }}{\text { arg4-1 }}\right.$ $\left.\frac{\text { MET } 13}{\text { met } 13} \frac{\text { can } 1}{C A N 1} \frac{C Y H 2}{c y h 2}\right)$ described in detail previously (Dawes et al., 1980) was used throughout. 
Growth and sporulation. Vegetative cells were grown with shaking at $30{ }^{\circ} \mathrm{C}$ in YEPA medium $[1 \%(w / v)$ yeast extract, $2 \%(\mathrm{w} / \mathrm{v})$ peptone, $2 \%(\mathrm{w} / \mathrm{v})$ potassium acetate]. Sporulation was initiated by the method of Fast (1973) by resuspending cells grown on YEPA to a turbidity of $1\left(A_{600}\right)$ at a fivefold concentration in $2 \%(\mathrm{w} / \mathrm{v})$ potassium acetate containing L-histidine $\left(50 \mu \mathrm{g} \mathrm{ml}^{-1}\right)$, penicillin $\left(1000\right.$ units $\left.\mathrm{ml}^{-1}\right)$ and tetracycline $\left(20 \mu \mathrm{g} \mathrm{ml}^{-1}\right)$ and incubating at $30^{\circ} \mathrm{C}$ with shaking.

Spore preparation. Sporulation cultures $(200 \mathrm{ml})$ contained after $2 \mathrm{~d}$ incubation $80-90 \%$ asci. These were pelleted by centrifugation at $5000 \mathrm{~g}$ for $5 \mathrm{~min}$ and resuspended in $10 \mathrm{ml}$ citrate/phosphate buffer $(0.1 \mathrm{M}$-sodium citrate, $0 \cdot 2 \mathrm{M}$-sodium phosphate, $\mathrm{pH} 4 \cdot 8$ ) containing $10 \%$ (v/v) crude $\beta$-glucuronidase (Helix pomatia gut extract; Sigma). The suspension was incubated at $30^{\circ} \mathrm{C}$ until dissolution of the ascal wall was evident on microscopical examination (between 2 and $4 \mathrm{~h}$ ). All subsequent operations were done at $0^{\circ} \mathrm{C}$. The mixture containing mainly ascospores with some asci was washed with distilled water and resuspended in $10 \mathrm{ml}$ distilled water. Spores were released from asci by extrusion through a French pressure cell at $27.6 \mathrm{MPa}$, yielding a suspension containing free spores, some whole cells and ascal wall debris. The spores were separated from other material by differential centrifugation: the suspension was made up to $200 \mathrm{ml}$ with distilled water and centrifuged at $1000 \mathrm{~g}$ for $1 \mathrm{~min}$ to pellet whole cells and unbroken asci. The supernatant, containing free spores, ascal walls and other cell debris was centrifuged at $1200 \mathrm{~g}$ for $10 \mathrm{~min}$ to pellet spores free of most contamination. This pellet was resuspended in $200 \mathrm{ml}$ distilled water and centrifuged at $2000 \mathrm{~g}$ for $10 \mathrm{~min}$ to further remove small debris. Recovery by this method is not quantitative but the yield can be improved if necessary by reprocessing fractions that would otherwise have been discarded, checking microscopically at each step for the extent of spore separation. The final spore pellet was resuspended in distilled water and washed further to a total of twenty times, centrifuging at $3000 \mathrm{~g}$ for $1 \mathrm{~min}$ between each wash; this was done to remove as much extraneous protein and cell debris as possible. After about the tenth wash it was noticed that some spores began to clump at the air/water interface; when this happened, the top $5 \mathrm{ml}$ of supernatant was collected and stored after each subsequent wash.

Preparation of antiserum. Antispore antiserum was prepared in New Zealand white rabbits by injecting subcutaneously $1 \mathrm{ml}$ spore suspension $\left(10^{9}\right.$ spores $\left.\mathrm{ml}^{-1}\right)$ emulsified with an equal volume of Freund's incomplete adjuvant (Difco) divided between four sites. After six weeks, the rabbits were boosted using the same regimen, and were bled $10 \mathrm{~d}$ later. Rabbits were subsequently boosted at monthly intervals.

Titration of antiserum. Initially, antisera were titrated using doubling dilutions in a microtitre tray, incubating equal volumes of antiserum and spore suspension $\left(0 \cdot 1 \mathrm{ml}\right.$ containing about $10^{8}$ spores $)$ at $37^{\circ} \mathrm{C}$ for $2 \mathrm{~h}$, then at $4{ }^{\circ} \mathrm{C}$ overnight. Clumping of spores was detected by microscopic examination. Control serum from an uninoculated rabbit was used to monitor self-agglutination and non-specific agglutination of spores. The same results were obtained more conveniently by mixing equal volumes $(10 \mu \mathrm{l})$ of antiserum and spore suspension on a microscope slide, covering the mixture with a coverslip and leaving the slide on damp filter paper in a Petri dish at ambient temperature. Agglutination of spores was complete within $15 \mathrm{~min}$, and self-agglutination of spores occurred only at the air/liquid interface.

Spore-specific antiserum. This was prepared by absorbing out anti-vegetative cell antibodies. Vegetative yeast cells were prepared by growth on YEPA medium, harvested, washed in distilled water and resuspended in distilled water at about $10^{9} \mathrm{ml}^{-1}$. This suspension was added to twice the volume of antiserum and the mixture incubated for $2 \mathrm{~h}$ at ambient temperature. Vegetative cells were removed by centrifugation at $5000 \mathrm{~g}$ for $5 \mathrm{~min}$, and the supernatant was tested for its ability to agglutinate vegetative cells. Any residual anti-vegetative activity was removed where necessary by repeating this procedure.

Preparation of cell extracts. Cells were harvested from sporulation cultures by centrifugation, washed with distilled water and, after suspending them in one-fifth of the culture volume of $0.01 \mathrm{M}$-Tris/ $\mathrm{HCl}$ buffer $(\mathrm{pH} \mathrm{7.2)}$ containing $1 \mathrm{~mm}$-EDTA and $2 \mathrm{mM}$-phenylmethylsulphonylfluoride, they were broken by grinding with glass beads as described previously (Vezinhet et al., 1979). For extracts of the soluble proteins the crude cell extracts were centrifuged at $150000 \mathrm{~g}$ for $1 \mathrm{~h}$ and the supernatants retained.

Antibody inhibition assays. Cell or spore extracts were adjusted to a protein concentration of $3 \mathrm{mg} \mathrm{ml}^{-1}$ and diluted serially ( 1 in 2) to final volumes of $40 \mu \mathrm{l}$ in Eppendorf centrifuge tubes. To each tube was added $20 \mu \mathrm{l}$ of spore-specific antiserum and the mixture was incubated for $1 \mathrm{~h}$ at room temperature. When whole cell or spore extracts were used, the mixtures were centrifuged $(5000 \mathrm{~g}, 5 \mathrm{~min})$ to remove debris, and $20 \mu \mathrm{l}$ of sonicated spore suspension $\left(10^{9}\right.$ spores $\left.\mathrm{ml}^{-1}\right)$ was added to the supernatant. Samples were examined microscopically after $1 \mathrm{~h}$ incubation at room temperature to detect any agglutination of spores. The intermediate centrifugation step was omitted for soluble extracts.

Protein estimation. Protein concentrations were estimated by the Lowry method using bovine serum albumin as standard.

Spore agglutination by lectins. Equal volumes $(10 \mu \mathrm{l})$ of spore suspension (about $\left.10^{8} \mathrm{ml}^{-1}\right)$ and lectin $\left(10 \mathrm{mg} \mathrm{ml}^{-1}\right)$ were mixed on a microscope slide and agglutination was detected as described previously.

Spore treatments. Spores were treated with either $1 \%(\mathrm{w} / \mathrm{v})$ SDS, $0 \cdot 1 \%(\mathrm{w} / \mathrm{v})$ DTT, or a combination of both, for $4 \mathrm{~h}$ at ambient temperature and were washed twice with distilled water before agglutination tests were done. 
Table 1. Spore and vegetative cell agglutination by antisera raised by injection of purified spores

Serum

Anti-spore

Anti-spore absorbed

with vegetative cells

Anti-spore absorbed

with ascospores

Non-immune

Agglutination of
vegetative cells* $\quad \begin{gathered}\text { Agglutination of } \\ \text { spores* }\end{gathered}$

$\begin{array}{ll}8 & 64 \\ 0 & 16 \\ 0 & 0 \\ 0 & 0\end{array}$

* Figures represent the highest dilution of serum at which at least $50 \%$ of the spores were agglutinated. The same results were obtained using microtitre tray and slide agglutination tests, and results were duplicated several times throughout the course of the work.

\section{RESULTS}

\section{Activity and specificity of antiserum to whole spores}

The antiserum raised against whole spores was found to cause agglutination of vegetative cells as well as spores but was less active against vegetative cells, causing agglutination of at least $50 \%$ of the cells at a titre of 1 in 8 compared with 1 in 64 for spore agglutination. However, a specific anti-spore antigen was demonstrated by absorbing out anti-vegetative cell activity with an excess of vegetative cells. This gave a spore-specific antibody which caused agglutination of spores at a titre of 1 in 16 without there being any detectable activity against vegetative cells or asci (Table 1).

In a reciprocal experiment to test the antiserum for specific anti-vegetative cell activity it was found that antiserum absorbed out against spores did not agglutinate vegetative cells. This could have resulted from some contamination with vegetative cell debris of the spores used to inoculate the rabbits, or from the existence of an antigenic determinant that was common to both the spore and the vegetative cell surfaces.

The results confirmed the findings of Snider \& Miller (1966) that there is at least one antigen present on the yeast ascospore surface that is not on vegetative cells or on the ascal surface. The antiserum used here enabled us to investigate the nature of the antigenic determinant and also the timing of its appearance during sporulation.

\section{Nature of the antigenic determinants of the anti-spore and the anti-vegetative cell activities}

Since one of the main antigenic determinants of the vegetative cell is mannan (Ballou, 1976), sugar inhibition tests were carried out using a range of mono- and disaccharides at a final concentration of $20 \%(\mathrm{w} / \mathrm{v})$ to test whether the antigenic determinant was carbohydrate in nature. Of the sugars glucose, galactose, fructose, mannose, $\mathrm{N}$-acetylglucosamine, lactose, maltose, cellobiose, sucrose and trehalose, only mannose had any effect. Mannose completely inhibited the agglutination of vegetative cells by whole serum but had no effect on spore agglutination by the spore-specific antiserum. That the anti-vegetative activity was probably directed against mannan was confirmed by inhibition experiments using mannan and glucan preparations both from vegetative cell walls and from isolated spore coats (kindly provided by Dr I. W. Sutherland). Mannan (at a final concentration of $5 \%, w / v)$ from either vegetative cell or spore coat sources completely inhibited agglutination of vegetative cells, but not agglutination of spores by the spore-specific antiserum. Glucan had no effect. While there is much to be done on the chemistry of the yeast spore coat, preliminary results have indicated that the two main sugar components are glucose and mannose, and that only a trace of amino sugars is present (I. W. Sutherland, personal communication).

Exposure of mannan at the spore surface could account for the inability to obtain any specific anti-vegetative cell activity by absorption with purified spores. Lectins that interact with $D$ mannosyl residues (concanavalin A and lentil lectin) caused agglutination of spores and, since lentil lectin is specific for D-mannosyl residues, it is clear that some mannan is exposed at the surface of the spores prepared by the methods used. 
Table 2. Timing of the appearance during sporulation of the spore-specific antigen in whole cell extracts and in $150000 \mathrm{~g}$ supernatants of cell extracts

Extracts were prepared from cells harvested at different times after resuspension in sporulation medium and were adjusted to a protein concentration of $3 \mathrm{mg} \mathrm{ml}^{-1}$ before use in the inhibition assay. A positive result indicates absence of antigen from the extract.

\begin{tabular}{|c|c|c|c|c|}
\hline \multirow{3}{*}{$\begin{array}{l}\text { Sporulation } \\
\text { time } \dagger \\
\text { (h) }\end{array}$} & \multicolumn{4}{|c|}{ Spore agglutination by spore-specific antiserum* } \\
\hline & \multicolumn{2}{|c|}{$\begin{array}{l}\text { Treated with whole } \\
\text { cell extract diluted: }\end{array}$} & \multicolumn{2}{|c|}{$\begin{array}{c}\text { Treated with } \\
\text { supernatant diluted: }\end{array}$} \\
\hline & 1 in 2 & 1 in 4 & 1 in 2 & 1 in 4 \\
\hline 0 & + & + & + & + \\
\hline 4 & + & + & + & + \\
\hline $7 \cdot 5$ & $+1-$ & + & + & + \\
\hline 9 & $+1-$ & + & $+1-$ & + \\
\hline 11 & - & + & - & - \\
\hline $12 \cdot 5$ & - & + & - & - \\
\hline 15 & - & $+1-$ & - & $+1-$ \\
\hline $17 \cdot 5$ & - & - & - & $+1-$ \\
\hline 20 & - & - & - & + \\
\hline
\end{tabular}

\footnotetext{
* + indicates complete agglutination of ascospores; $+/-$, some agglutination, but free spores also present; - , no spore agglutination.

† Similar results were obtained on repeating the experiment to study the effect of cycloheximide inhibition, although there was a slight shift in the timing of all events.
}

From the negative result of sugar inhibition tests it seemed likely that the spore-specific antigenic activity was not primarily determined by a carbohydrate. Various attempts were, therefore, made to define the nature of this activity. Treatment of the spores with either $8 \mathrm{M}$-urea or the relatively non-specific proteinase from Streptomyces griseus was tried, but this led to very extensive self-agglutination of the spores which could not be alleviated by treatments with EDTA, buffers of different ionic composition, ionic strength or $\mathrm{pH}$, or by solvents such as ethanol or diethyl ether. However, some indication that the spore surface antigen involves a protein was obtained by treating the spores with a SDS/DTT mixture. A slight reduction in spore agglutination by the spore-specific antiserum was noted (from a titre of 1 in 16 to 1 in 8) on treating the spores with SDS, and the combined action of SDS and DTT caused a marked reduction in spore agglutination (to a titre of 1 in 4). DTT treatment in the absence of SDS had no effect, and the lack of agglutination of SDS/DTT-treated spores was probably not due to residual reagents in inhibiting the reaction, since $1: 1$ mixtures of treated : untreated spores showed agglutination.

\section{Timing of appearance of the spore-specific antigen}

An inhibition method was used to detect the appearance of the spore-specific antigen during sporulation. Anti-spore antiserum was preincubated with various dilutions of an extract of sporulating cells to remove some, or all, of the anti-spore antibody, and this pretreated antiserum was incubated with spores to detect remaining antibody. Undiluted extract was found to cause non-specific effects and was therefore not used. To avoid differences due to variable cell breakage, extracts were adjusted to the same protein concentration $\left(3 \mathrm{mg} \mathrm{ml}^{-1}\right)$ prior to dilution.

Table 2 illustrates the results obtained using whole extracts from cells harvested at different times during sporulation. In this strain under the conditions used, premeiotic DNA replication began about $4 \mathrm{~h}$ after resuspension and asci could be detected after $15 \mathrm{~h}$, reaching a maximum of about $70 \%$ by $24 \mathrm{~h}$. It can be seen from Table 2 that the spore-specific antigen was first detected after $7.5 \mathrm{~h}$, and that it continued to be formed during the rest of the sporulation process. This early appearance was reproducible and occurred well before the formation of recognizable ascospores. The synthesis of the spore-surface antigen, therefore, begins many hours before the spore surface is assembled, in a way similar to the synthesis of some of the spore-coat proteins of 
Bacillus subtilis (Muñoz et al., 1978; Pandey \& Aronson, 1979; Jenkinson et al., 1981). This was confirmed by showing that from an early stage in sporulation the spore surface antigen was present in the soluble supernatant after centrifugation at $150000 \mathrm{~g}$ (Table 2). As sporulation continued beyond $15 \mathrm{~h}$ from resuspension, the amount of antigen in the soluble fraction decreased, presumably as it was being assembled on to the surface of the spore.

\section{Appearance of the spore-specific antigen depends on protein synthesis}

Formation of the spore-specific antigen was sensitive to inhibition by cycloheximide $\left(100 \mu \mathrm{g} \mathrm{ml}^{-1}\right)$ added at times up to its first appearance at about $9 \mathrm{~h}$ after resuspension. This was found by adding cycloheximide to sporulating cultures at different times after resuspension, allowing each culture to continue incubation under sporulation conditions for a total of $24 \mathrm{~h}$, and then assaying the soluble supernatant for presence of the spore-specific antigen by the inhibition assay.

\section{DISCUSSION}

Rabbit antisera raised against purified ascospores recognized both vegetative cells and ascospores, causing agglutination. The anti-vegetative cell activity was directed against mannan and was probably due to mannan exposed at the surface of the ascospore since lectin binding studies demonstrated clearly that D-mannosyl residues were exposed at the spore surface. Moreover, spore mannan purified from the spore coat strongly inhibited the agglutination of vegetative cells.

The spore-specific activity, however, seems to be determined largely by a protein or proteins, since extraction of spores with a mixture of SDS and DTT led to a marked decrease in their agglutinability by the spore-specific antiserum. The inhibition of formation of the spore antigen by cycloheximide is not necessarily an indication that it is a protein, but it does show that cytoplasmic protein synthesis is required for synthesis of the spore-specific antigen at all times up to and including its expression. A more sensitive assay for the antigen than the inhibition method used here must be developed before the kinetics of this inhibition can be studied in detail.

Clearly, more work is also required on the chemistry of the yeast spore coat structure. A likely candidate for the spore antigen is the electron-dense outer layer of the spore that arises from the prospore wall (Moens, 1971; Moens \& Rapport, 1971) also described as the forespore membranes (Guth et al., 1972) or the spore-delimiting membranes (Beckett et al., 1973). The outer of these membranes becomes much more electron dense as the spore matures. It can be removed by $8 \mathrm{M}$-urea or partially by treatment with proteinases (Briley et al., 1970) and these authors suggest that it may confer on the spore its electrophoretic mobility characteristics. Unfortunately, these treatments also lead to self-agglutination of spores and it is not, therefore, possible to test directly whether they remove the specific antigen.

The appearance of the surface antigen provides a very useful marker event for analysis of the regulation of the later stages of sporulation that follow meiosis. To date there have been few biochemical changes unique to sporulation that have been identified and, with the exception of a sporulation-specific $\alpha$-glucosidase activity (Clancy et al., 1982), those changes that have been detected have been found by gel electrophoresis analysis (Wright et al., 1981) and their function is not known. It is interesting that the surface antigen appears in a soluble form several hours before the spore surface is formed, and that this soluble pool subsequently declines. Presumably, this reflects assembly of the antigen on to the spore surface. This is similar to the assembly of the bacterial spore coat, since in Bacillus spp. spore coat proteins appear in a soluble form in sporulating cells at a stage much in advance of the assembly of the spore coat (Wood, 1972; Muñoz et al., 1978; Pandey \& Aronson, 1979; Jenkinson et al., 1981).

With the availability of an antiserum directed against the spore surface antigen in yeast the way is now open for a more detailed examination of its structure, function and the regulation of its synthesis. 
We wish to thank Dr I. W. Sutherland for the provision of spore and vegetative cell mannans and glucans, and for helpful discussion. The work was supported by the Science Research Council and the Medical Research Council.

\section{REFERENCES}

Ballou, C. (1976). Structure and biosynthesis of the mannan component of the yeast cell envelope. Advances in Microbial Physiology 14, 93-158.

Beckett, A., Illingworth, R. F. \& Rose, A. H. (1973). Ascospore wall developments in Saccharomyces cerevisiae. Journal of Bacteriology 113, 1054 1057.

Briley, M. S., Illingworth, R. F., Rose, A. H. \& FisheR, D. J. (1970). Evidence for a surface protein layer on the Saccharomyces cerevisiae ascospore. Journal of Bacteriology 104, 588-589.

Clancy, M. J., Smith, L. M. \& Magee, P. T. (1982). Developmental regulation of a sporulation-specific enzyme activity in Saccharomyces cerevisiae. Molecular and Cellular Biology 2, 171-178.

Dawes, I. W., Wright, J. F., Vezinhet, F. \& AJam, N. (1980). Separation on Urografin gradients of subpopulations from sporulating Saccharomyces cerevisiae cultures. Journal of General Microbiology 119, 165-171.

Esposito, R. E. \& KLapholz, S. (1981). Meiosis and ascospore development. In The Molecular Biology of the Yeast Saccharomyces: Life Cycle and Inheritance, pp. 211-287. Edited by J. N. Strathern, E. W. Jones \& J. R. Broach. New York: Cold Spring Harbor Laboratory.

Esposito, R. E., Frink, N., Bernstein, P. \& Esposito, M. S. (1972). The genetic control of sporulation in Saccharomyces. II. Dominance and complementation of mutants of meiosis and spore formation. Molecular and General Genetics 114, 241-248.

FAST, D. (1973). Sporulation synchrony of Saccharomyces cerevisiae in various carbon sources. Journal of Bacteriology 116, 925-930.

Guth, E., Hashimoto, T. \& Contı, S. (1972). Morphogenesis of ascospores in Saccharomyces cerevisiae. Journal of Bacteriology 109, 869-880.
Jenkinson, H. F., Sawyer, W. D. \& Mandelstam, J. (1981). Synthesis and order of assembly of spore coat proteins in Bacillus subtilis. Journal of General Microbiology 123, 1-16.

MoEnS, P. B. (1971). Fine structure of ascospore development in the yeast Saccharomyces cerevisiae. Canadian Journal of Microbiology 17, 507-510.

MoEns, P. B. \& RAPPORT, E. (1971). Spindles, spindle plaques and meiosis in the yeast Saccharomyces cerevisiae (Hansen). Journal of Cell Biology 50, 344-361.

Muñoz, L. E., Nakayama, T. \& DoI, R. H. (1978). Expression of spore coat protein gene, an "early sporulation gene", and its relationship to RNA polymerase modification. In Spores VII, pp. 213219. Edited by G. Chambliss \& J. C. Vary. Washington, D.C.: American Society for Microbiology.

Pandey, N. K. \& Aronson, A. I. (1979). Properties of the Bacillus subtilis spore coat. Journal of Bacteriology 137, 1208-1218.

SNider, I. I. \& Miller, J. J. (1966). A serological comparison of vegetative cell and ascus wall and the spore coat of Saccharomyces cerevisiae. Canadian Journal of Microbiology 12, 485-488.

VEZINHET, F., KinNAIRD, J. H. \& DAWES, I. W. (1979). The physiology of mutants derepressed for sporulation in Saccharomyces cerevisiae. Journal of General Microbiology 115, 391-402.

Wood, D. A. (1972). Sporulation in Bacillus subtilis. Properties and time of synthesis of alkali-soluble protein of the spore coat. Biochemical Journal 130, 505-514.

Wright, J. F., AJAM, N. \& Dawes, I. W. (1981). Nature and timing of some sporulation-specific protein changes in Saccharomyces cerevisiae. Molecular and Cellular Biology 1, 910-918. 